\title{
STANDAR PENGUJIAN KUALITAS BATA PENGGANTI
}

Oleh

Ari Swastikawati, S.Si, M.A

Balai Konservasi Peninggalan Borobudur

\section{A. Pengantar}

Indonesia merupakan negara yang kaya akan tinggalan cagar budaya. Tinggalan cagar budaya tersebut tersebar di seluruh wilayah Nusantara. Material cagar budaya yang ada di seluruh wilayah nusantara tersebut, terdiri dari berbagai jenis material seperti cagar budaya berbahan bata, batu, kayu, logam, keramik dan lain-lain. Salah satu material cagar budaya yang banyak terdapat di Pulau Jawa dan Sumatera adalah cagar budaya berbahan bata. Cagar budaya berbahan bata tersebut dapat berupa candi, gapura, sumur, saluran air dan lain-lain.

Cagar budaya berbahan bata merupakan jenis cagar budaya yang sangat rentan terhadap proses kerusakan dan pelapukan, baik oleh proses fisik, mekanik, biologis dan kimia. Dampak yang ditimbulkan oleh adanya proses kerusakan dan pelapukan tersebut antara lain:

- pertumbuhan organisme baik algae, moss, lichen

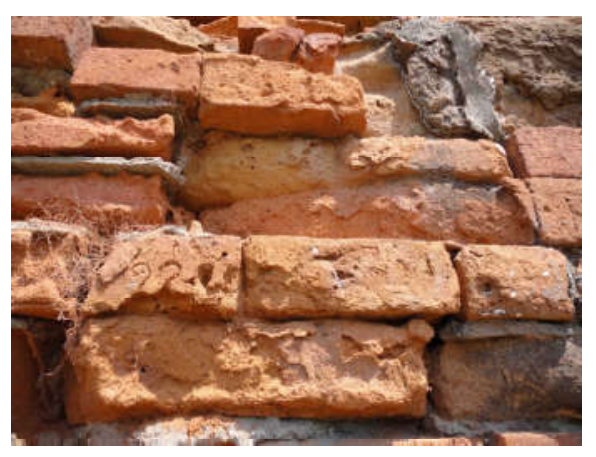

Gambar 1. Kerusakan dan Pelapukan Bata Pengganti pada Candi Brahu di Trowulan, Jawa Timur

- adanya retakan dan kerapuhan tingkat tinggi pada material bata.

Berbagai upaya tindakan konservasi dan pemugaran dilaksanakan untuk meminimalisasi atau menghambat proses kerusakan dan pelapukan lebih lanjut seperti:

1. Pemberian bahan penolak air (water repellent) dan lapisan kedap air (water proofing) untuk menghambat masuknya air ke dalam struktur bangunan bata.

2. Pemasangan struktur beton untuk memperkuat struktur bangunan baik pada bagian dalam maupun pada bagian lantai atau dasar.

3. Pembenahan sistem drainase di lingkungan bangunan bata.

4. Penggunaan bata penganti untuk mengantikan bata yang sudah sangat rapuh dan tidak dapat dipasang lagi.

Akan tetapi berbagai teknik konservasi dan pemugaran tersebut tidak sepenuhnya dapat menyelesaikan masalah. Salah satu contoh kasus yang terjadi pada Candi Brahu di Trowulan, Mojokerto Jawa Timur. Setelah dilakukan tindakan konservasi dan pemugaran ternyata proses kerusakan dan pelapukan bata pengganti terjadi sangat cepat. Hal ini menunjukan bahwa bata penganti yang digunakan memiliki kualitas yang rendah. Oleh karena itu perlu kiranya sebelum digunakan sebagai bata penganti dalam kegiatan konservasi dan pemugaran maka bata-bata tersebut harus lolos dari proses pengujian. Sehingga bata pengganti dapat terjamin kualitasnya dengan baik. Untuk melakukan pengujian kualitas bata yang baik maka diperlukan standar pengujian kualitas bata pada laboratorium di lingkungan Direktorat Tinggalan Purbakala. Sehingga setiap laboratorium di lingkungan Direktorat Tinggalan Purbakala dapat menentukan, lolos tidaknya material bata yang akan dijadikan sebagai bata pengganti.

\section{B. Bata Merah Secara Umum}

Bata merah dibuat dari tanah liat atau lempung dengan atau tanpa campuran bahan lain, yang dibakar pada suhu yang tinggi sehingga tidak hancur lagi bila direndam air. Pada awal proses pembuatan bata, tanah liat dibuat plastis, kemudian dicetak dalam cetakan kayu atau baja. Tanah hasil cetakan tersebut kemudian dikeringkan, selanjutnya dibakar pada suhu yang tinggi.

Material bata yang baik terdiri atas pasir (silika) dan tanah liat (alumina), yang dicampur dalam perbandingan tertentu sehingga bila ditambahkan dengan sedikit air menjadi bersifat plastis. Sifat plastis tersebut sangat penting agar tanah dapat dicetak dengan mudah, dikeringkan tanpa susut, retak-retak maupun melengkung. Jika terlalu banyak tanah liat (kurang pasir) akan mengakibatkan susutan bata menjadi sangat besar selama proses pengeringan dan pembakaran, juga menyebabkan bata menjadi retak dan melengkung. Penambahan pasir dapat menghilangkan pengaruh buruk tersebut, tetapi jika pasir ditambahkan dalam jumlah terlalu banyak akan menyebabkan tidak adanya lekatan antar butiran dan akibatnya bata menjadi getas dan lemas. Di dalam campuran tersebut juga terdapat sedikit kapur dalam 
bentuk bubuk, yang berfungsi untuk membantu proses pelelehan pasir saat proses pembakaran, dan sebagai pengikat butir-butir tanah. Jika ada kapur yang tidak berbentuk bubuk (lebih besar) maka butir kapur menjadi $\mathrm{CaO}$ (kapur tohor) setelah proses pembakaran. Butir kapur tohor tersebut akan bereaksi dan mengembang bila terkena air, hal ini menyebabkan bata menjadi retak. Begitu pula jika, terlalu banyak kapur maka bata akan menjadi mudah retak. Selain kapur bata juga mengandung sedikit oksida besi, oksida besi yang berfungsi untuk menyempurnakan proses pembakaran seperti kapur dan memberi warna merah setelah proses pembakaran. Kekurangan oksida besi menyebabkan bata berwarna kuning (kurang gelap).

Umumnya bata berbentuk empat persegi panjang, bersudut siku-siku, tajam, dan permukaannya rata. Panjang bata umumnya dua kali lipat lebarnya, sedangkan tebalnya sekitar setengah atau tiga perempat lebarnya. Sedangkan ukuran bata merah standar adalah: panjang $230 \mathrm{~mm}$, lebar $110 \mathrm{~mm}$ dan tebal $50 \mathrm{~mm}$.

\section{Standar Pengujian Kualitas Bata}

Standar pengujian kualitas bata diperlukan untuk menjamin kualitas bata penganti memiliki kualitas yang baik. Adapun metode pengujian kualitas bata dapat dilakukan dengan mempertimbangkan beberapa parameter diantaranya ukuran bata, daya serap air, temperatur pembakaran, kuat tekan, serta kadar garam yang larut dan membahayakan. Kelima parameter tersebut dipilih karena parameter-parameter tersebut memiliki standar atau kriteria yang dapat dijadikan sebagai acuan.

\section{a) Ukuran dan Warna Bata Penganti}

Ukuran dan warna bata penganti seharusnya disesuaikan dengan ukuran dan warna bata asli. Sekalipun akan sangat sulit menyamakan warna bata penganti dengan warna bata asli karena bata asli umumnya sudah mengalami perubahan warna karena proses degradasi, terutama bata outer. Begitu pula ukuran bata pengganti karena bata asli pada bangunan candi umumnya sudah mengalami proses pemacakan saat dipasang. Sehingga permukaan bata pada beberapa atau seluruh sisinya sudah berkurang 0,5 sampai $1 \mathrm{~cm}$. Berikut ini contoh ukuran bata asli pada beberapa candi di Indonesia:

\section{b) Uji Serap Air}

Bata merupakan material yang bersifat higroskopis artinya mudah menyerap air. Bata yang berkualitas tinggi akan memiliki daya serap yang rendah terhadap air dan kelembapan, sebaliknya bata yang berkualitas rendah akan memiliki daya serap yang tinggi terhadap air dan kelembapan.

\begin{tabular}{|c|c|c|c|}
\hline \multirow{2}{*}{ Nama Candi } & \multicolumn{3}{|c|}{ Ukuran bata $(\mathbf{c m})$} \\
\cline { 2 - 4 } & panjang & lebar & tebal \\
\hline Muara Jambi & $24-35$ & $14-22$ & $4-8$ \\
\hline Bumiayu & $29-36$ & $19-22$ & $10-12$ \\
\hline Muara Takus & 25 & 15 & 4 \\
\hline Segaran & 36 & 22 & 8 \\
\hline Brahu & 35 & 20 & 8 \\
\hline Lawang & 34 & 20 & 6 \\
\hline Tikus & 37 & 22 & 8 \\
\hline
\end{tabular}

Umumnya bata dianggap baik bila memiliki daya serap air kurang dari $20 \%$. Untuk itu perlu dilakukan uji daya serap air bata, sebagai berikut:

\section{Peralatan dan bahan yang digunakan:}

- tiga sampel bata

- timbangan digital

- benjana berisiair

\section{Proseduruji:}

- Sampel bata ditimbang dalam keadaan kering mutlak (Wk)

- Bata kemudian direndam dalam air sampai semua pori terisi air (tidak ada gelembung udara yang keluar).

- Bata yang telah direndam dalam air ditimbang kembali (Wb)

- Besarnya serapan air dihitung sebagai berikut:

$$
P=\frac{W b-W k}{W k} \times 100 \%
$$

Keterangan:

$\mathrm{P}$ : persentase air yang terserap bata (\%)

Wk : berat bata kering mutlak sebelum direndam air (gr)

$\mathrm{Wb}$ : berat bata setelah direndam dalam air (gr)

\section{c) Temperatur Pembakaran Bata}

Kualitas bata, baik bata asli maupun bata pengganti sangat dipengaruhi oleh suhu pembakarannya. Temperatur berguna dalam proses pengeringan bata sehingga diperoleh bata yang baik dan sempurna. Dalam campuran tanah liat dan air sebelum dibakar, di dalam strukturnya masih terdapat berbagai jenis air yaitu:

1. Air suspensi (percampuran air dengan bahan dasar)

2. Air antar partikel yang terjadi pada waktu melumatkan bahan dasar

3. Air pori antar partikel setelah pengkerutan 
4. Air terabsorpsi secara kimia atau fisik partikel

5. Air kisi dalam struktur kristalnya

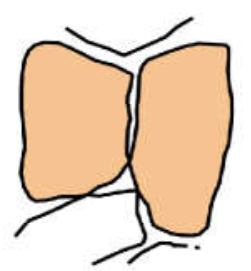

(a)

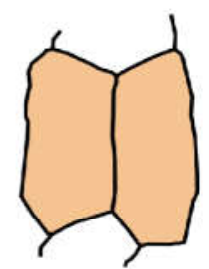

(b)
Gambar 2.

(a) bata sebelum dibakar

(b) bata setelah dibakar

Air yang terabsopsi fisik hilang pada pemanasan $100^{\circ} \mathrm{C}$, sedangkan air terabsorpsi kimia dalam bentuk $\mathrm{H}_{3} \mathrm{O}^{+}$ atau $\mathrm{OH}$ hilang pada temperatur $1000^{\circ} \mathrm{C}$. Air gugus hidroksida mulai lepas pada suhu $600^{\circ} \mathrm{C}$. Oleh karena itu bata yang temperatur pembakarannya kurang dari $600^{\circ} \mathrm{C}$ akan mudah rapub karena gugus hidroksidanya belum lepas.

Dalam proses pembakaran akan terjadi pemampatan karena partikel-partikel lempung akan mengelompok menjadi bahan padat, permukaan bata akan menyusut, volume berkurang dan struktur bata akan bertambah kuat kemudian permukaan butiran yang berdekatan akan saling menyatu seperti terillustrasi pada Gambar 2. Secara umum semakin tinggi dan semakin lamaprosespembakaran, maka kualitas bata yang dibasilkan akan semakin baik. Temperatur yang ideal untuk pembakaran bahan-bahan keramik adalah $900^{\circ} \mathrm{C}$, dimana pada temperatur tersebut kristal silika akan meleleh secara efektif dan mengalami rekristalisasi secara sempurna. Pada pembuatan bata temperatur tersebut sulit dicapai, karena pembakarannya menggunakan bahan bakar langsung tanpa menggunakan ruang tanur.

Bahan bakar yang digunakan saat pembakaran bata dapat berupa kayu atau sekam padi. Temperatur yang dapat dicapai pada pembakaran menggunakan kayu lebih baik dibanding dengan menggunakan sekam, disamping temperaturnya dapat lebih tinggi juga adanya unsur karbon, sehingga bata menjadi keras. Informasi bahan bakar yang digunakan pada bata asli penting untuk diketahui. Analisis terhadap bata asli perlu memperhatikan adanya sisa-sisa arang bahan pembakar yang sering kali masih menempel pada permukaan bata.

Berdasarkan pengalaman analisis yang dilakukan di laboratorium BKPB dengan metode DTA (Differential Thermal Analysis), ditemukan temperatur pembakaran bata berkisar antara $250-800^{\circ} \mathrm{C}$. Berdasarkan keseluruhan uraianya di atas maka sebaiknya bata pengganti dibakar pada suhu pembakaran antara $600-800^{\circ} \mathrm{C}$. Adapun peralatan dan prosesdur analisa suhu pembakaran bata sebagai berikut:

\section{Peralatan dan bahan yang digunakan: \\ - DTA dengan suhu pembakaran $0-1200^{\circ} \mathrm{C}$ \\ - Cawan porselin \\ - Color chart \\ - Penjepitbesi \\ - Spidol permanen}

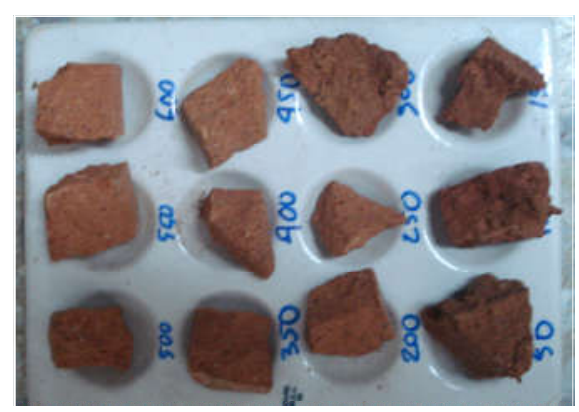

Gambar 3.

Penempatan potongan sample bata pada cawan porselin

\section{Proseduruji:}

- Sampel bata dipotong menjadi bagian-bagian kecil

- Temperatur pembakaran yang akan dilakukan ditulis pada cawan porselin misalnya 50, 100, 150, 200, 250, $300,350,400$, $450,500,550,600,650,700,750^{\circ} \mathrm{C}$ dan seterusnya

- Potongan bata diletakan pada cawan porselin, kemudian potongan bata diambil dan diletakan pada ruang alat DTA sesuai urutan suhu pembakaran pada cawan porselin

- Potongan bata tersebut diambil satu persatu setiap kenaikan suhu $50^{\circ} \mathrm{C}$.

- Potongan bata tersebut diletakan kembali pada cawan porselin, kemudian perubahan warna pada potongan bata dibandingkan dengan menggunakan color chart.

- Bata yang mulai mengalami perubahan warna menunjukan kisaran temperatur pembakarannya.

\section{d) Uji Garam Terlarut pada Bata Merah}

Bahan baku bata merah berasal dari tanah liat (lempung) dengan atau tanpa campuran bahan-bahan 
lain. Lempung berasal dari pelapukan batuan yang mengandung mineral. Mineral-mineral tersebut terdiri dari silika, alumunium dengan gabungan kalium, natrium, magnesium dan kalsium. Bata juga mengandung senyawa-senyawa lain baik dalam bentuk mineral maupun garam-garam terlarut.

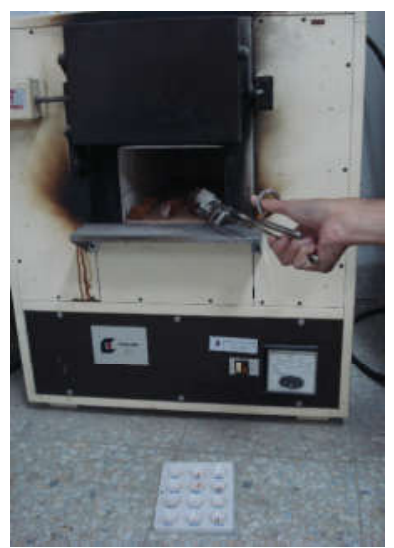

Gambar 4.

Penempatan potongan sample bata sesuai dengan urutan temperature pada cawan porselin

Senyawa-senyawa tersebut ada di dalam bata karena terkandung dalam bahan baku. Senyawa yang dapat berdampak negatif dalam jangka panjang adalah garam-garam terlarut yang dapat keluar ke permukaan bata oleh aktifitas air dalam material. Setelah keluar dapat menimbulkan pengaraman, dan lebih lanjut dapat menyebabkan pelapukan dan pengelupasan.

Meskipun demikian, penggaraman tidak akan terjadi jika bata yang digunakan tidak mengandung garam terlarut. Bata pengganti yang digunakan saat pemugaran, harus mengandung kadar garam terlarut seminimal mungkin. Berikut ini diuraikan cara metode uji garam terlarut menurut uji kualitas bata berdasar SNI (YDNI No. 10 tahun 1964):

Peralatan dan bahan yang digunakan:

- Bejana dangkal dengan dasar yang datar berukuran: luas alas dengan diameter 15 centimeter (bentuk silinder), atau 15 x 10 centimeter (bentuk persegi panjang) dan tinggi dinding kurang lebih 5 centimeter.

- Sampel bata (5 buah)

- Air suling (air murni)

\section{Prosedur uji:}

- Disiapkan minimal 5 sampel bata utuh, kemudian tiaptiap sampel ditempatkan pada bidang datar dalam posisi berdiri seperti terilustrasi pada Gambar 3 .

- Ke dalam masing-masing bejana dituangkan air suling sebanyak 250 cc. Bejana-bejana beserta benda-benda percobaan dibiarkan dalam ruang yang mempunyai pergantian udara yang baik.

- Jika sesudah beberapa hari air telah diisap dan bata-bata kelihatan kering, air yang sama banyaknya dituangkan lagi ke dalam bejana-bejana dan bata-bata dibiarkan lagi hingga kering. Kegiatan ini dilakukan kurang lebih selama tiga (3) bulan.

- Kemudian bata-bata diamati pengeluaran garam-garam putih pada permukaannya. Hasil pengamatan dinyatakan sebagai berikut:

a. Tidak membahayakan bila kurang dari 50\% permukaan bata tertutup lapisan garam.

b.Ada kemungkinan membahayakan

Bila 50\% atau lebih permukaan bata tertutup lapisan garam yang agak tebal.

c. Membahayakan

Bila lebih dari 50\% permukaan bata tertutup lapisan garam yang tebal dan bagian-bagian bata menjadi bubuk atau terlepas.

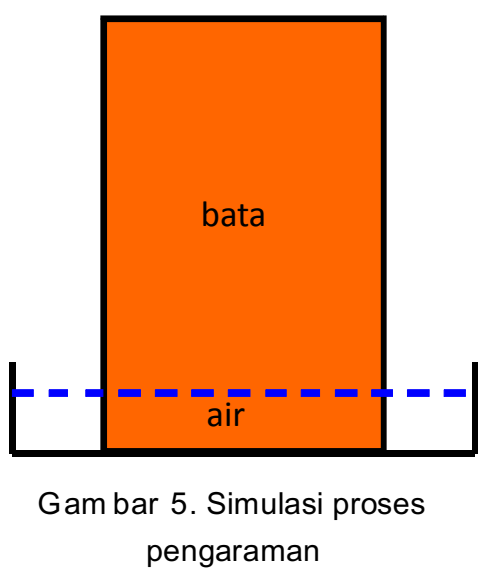

\section{e) Uji Kuat Tekan Bata}

Kuat tekan merupakan salah satu parameter yang digunakan untuk mengetahui kekuatan atau kemampuan suatu material atau benda untuk menahan tekanan atau beban. Nilai kuat tekan bata diperlukan untuk mengetahui kekuatan maksimum dari suatu benda untuk menahan tekanan atau beban hingga retak dan pecah. Kualitas bata biasanya ditunjukkan oleh besar kecilnya kuat tekan. Namun besar kecilnya kuat tekan sangat dipengaruhi oleh suhu atau tingkat pembakaran, porositas dan bahan dasar.

Rumus Kuat tekan:

$$
=\frac{P}{A} \mathrm{~kg} / \mathrm{cm}^{2}
$$


Keterangan:

$\mathrm{P}$ : beban yang diterima/tekanan $(\mathrm{kg})$

A: luas penampang $\left(\mathrm{cm}^{2}\right)$

Berdasarkan kuat tekannya (Anonim, 1964; 6), mutu bata merah dapat diklasifikasikan menjadi 3 tingkat, yaitu:

1. Tingkat I mempunyai kuat tekan rata-rata $>100$ $\mathrm{kg} / \mathrm{cm}^{2}$.

2. Tingkat II mempunyai kuat tekan antara $80-100$ $\mathrm{kg} / \mathrm{cm}^{2}$.

3. Tingkat III mempunyai kuat tekan antara $60-80$ $\mathrm{kg} / \mathrm{cm}^{2}$.

Adapun metode uji kuat tekan bata sebagai berikut:

Peralatan dan bahan yang diperlukan:

- Sampel bata sebanyak tiga (3) ulangan dengan ukuran $5 \times 5 \times 5 \mathrm{~cm}$ atau sampel bata berbentuk silinder dengan panjang bata dua kali panjang diameternya, misal diameter bata $5 \mathrm{~cm}$ maka panjang sampel bata $10 \mathrm{~cm}$. Sebelum dilakukan pengujian bata disimpan dengan temperatur $20^{\circ} \mathrm{C} \pm 2^{\circ} \mathrm{C}$ selama 5 sampai 6 hari. Permukaan sampel bata bagian atas dan bawah harus benar-benar rata.

- Jangka sorong

- Plat baja

- UTM (universal testing mechine)

Prosedur uji:

- Sampel bata diletakan pada plat baja bawah, sampel bata diatur pada posisi memanjang sehingga berada pada titik pusat sendi peluru pada plat baja atas.

- Plat baja diatur secara perlahan hingga menyentuh permukaan ujung bata uji secara merata.

- Jarum penunjuk pada manometer pengukur tekanan diatur dan dilakukan pembacaan awal

- Tekanan ditingkatkan sampai kondisi benda retak sampai pecah

- Hasil pembacaan manometer pada saat terjadi retakan bata uji dicatat

- Dibuat skesa bidang retak bata uji setelah mengalami retakan sampai pecah.

\section{Penutup}

Salah satu upaya untuk mencegah proses kerusakan dan pelapukan cagar budaya berbahan bata sebelum tindakan konservasi dan pemugaran dilaksanakan adalah dengan melakukan pemilihan bata penganti yang berkualitas baik. Untuk menentukan apakah bata penganti tersebut berkualitas baik atau tidak, maka diperlukan standar pengujian kualitas bata pengganti.
Adapun metode pengujian kualitas bata dapat dilakukan dengan mempertimbangkan beberapa parameter sebagai berikut, diantaranya: ukuran, daya serap air, temperatur pembakaran, kuat tekan, serta kadar garam yang larut dan membahayakan. Dengan adanya standar pengujian kualitas bata tersebut diharapkan bata pengganti yang digunakan dalam kegiatan konservasi dan pemugaran dapat terjamin kualitasnya dengan baik.

\section{DAFTAR PUSTAKA}

Croci, Giorgio. 1998. The Conservation and Structural Restoration of Architectural Heritage. Computational Mechanics Publications Southampton, UK and Boston, USA

Hartono, A.J. 1994. Mengenal Keramik Modern. Andi Offset, Yogyakarta

Mulyono. 1999. Studi Teknis Pengerjaan Bahan Pemugaran Bata. Balai Konservasi Peninggalan Borobudur.

Munandar, Aris. 2002. Perawatan dan Pengawetan Bangunan Bata. Balai Studi dan Konservasi Peninggalan Borobudur, Magelang.

Munandar, Aris; Sudibyo dan Muhsidi. 2004. Laporan Studi Teknik Pengerjaan Bahan Pemugaran Candi Bata Tahap IV. Balai Konservasi Peninggalan Borobudur, Magelang

Ramli dan Jusmaini. 2007. Pengaruh Pemberian Material Limbah Serat Alami Terhadap Sifat Fisika Bata Merah. Jurusan Fisika, Fakultas MIPA, Universitas Negeri Padang

Badan Standardisasi Nasional. 2008. Standar Nasional Indonesia (SNI 2825:2008): Cara Uji Kuat Tekan Batu Uniaksial. Badan Penelitian dan Pengembangan Departemen Pekerjaan Umum.

YDNI No. 10 (11 Januari 1964). Bata Merah sebagai Bahan Bangunan. Departemen Pekerjaan Umum (Lembaga Penyelidikan Masalah Bangunan), Bandung.

http:// www. elearning.gunadarma. bab 7.bata merah. Dikutip tanggal 6 April 2011. 